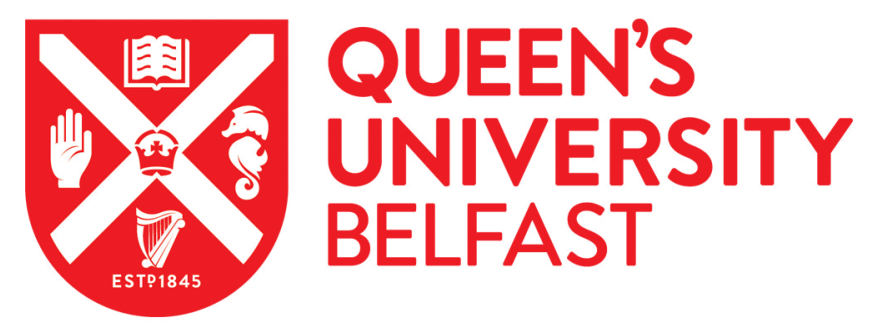

\title{
Outcome measures to assess the effectiveness of endodontic treatment for pulpitis and apical periodontitis for use in the development of European Society of Endodontology (ESE) S3 level clinical practice guidelines: A Protocol
}

Duncan, H. F., Nagendrababu, V., El Karim, I., \& Dummer, P. M. H. (2021). Outcome measures to assess the effectiveness of endodontic treatment for pulpitis and apical periodontitis for use in the development of European Society of Endodontology (ESE) S3 level clinical practice guidelines: A Protocol. International Endodontic Journal. https://doi.org/10.1111/iej.13501

Published in:

International Endodontic Journal

Document Version:

Peer reviewed version

Queen's University Belfast - Research Portal:

Link to publication record in Queen's University Belfast Research Portal

Publisher rights

Copyright 2021 Wiley.

This work is made available online in accordance with the publisher's policies. Please refer to any applicable terms of use of the publisher.

\section{General rights}

Copyright for the publications made accessible via the Queen's University Belfast Research Portal is retained by the author(s) and / or other copyright owners and it is a condition of accessing these publications that users recognise and abide by the legal requirements associated with these rights.

Take down policy

The Research Portal is Queen's institutional repository that provides access to Queen's research output. Every effort has been made to ensure that content in the Research Portal does not infringe any person's rights, or applicable UK laws. If you discover content in the Research Portal that you believe breaches copyright or violates any law, please contact openaccess@qub.ac.uk. 
MR. HENRY FERGUS DUNCAN (Orcid ID : 0000-0001-8690-2379)

DR. VENKATESHBABU NAGENDRABABU (Orcid ID : 0000-0003-3783-3156)

DR. IKHLAS EL KARIM (Orcid ID : 0000-0002-5314-7378)

Article type : Original Article

Outcome measures to assess the effectiveness of endodontic treatment for pulpitis and apical periodontitis for use in the development of European Society of Endodontology (ESE) S3 level clinical practice guidelines: A Protocol

H.F. Duncan ${ }^{1}$, V. Nagendrababu², I. El-Karim³ ${ }^{3}$ P.M.H. Dummer ${ }^{4}$

${ }^{1}$ Division of Restorative Dentistry \& Periodontology, Dublin Dental University Hospital, Trinity College Dublin, Lincoln Place, Dublin 2, Ireland; ' 2Department of Preventive and Restorative Dentistry, College of Dental Medicine, University of Sharjah, Sharjah, UAE; ${ }^{3}$ School of Medicine Dentistry and Biomedical Sciences, Queen's University Belfast, Belfast, UK; ${ }^{4}$ School of Dentistry, College of Biomedical and Life Sciences, Cardiff University, Cardiff, UK.

Running title: ESE S3 Guidelines Outcome Measures

Keywords: Guidelines, Effectiveness, Clinical outcome measure, Patient-reported outcomes, Clinicianreported outcomes, Follow-up, Endodontic treatment

\section{Corresponding author:}

Henry F. Duncan

This article has been accepted for publication and undergone full peer review but has not been through the copyediting, typesetting, pagination and proofreading process, which may lead to differences between this version and the Version of Record. Please cite this article as doi: 10.1111/IEJ.13501

This article is protected by copyright. All rights reserved 
Division of Restorative Dentistry \& Periodontology, Dublin Dental University Hospital, Trinity College Dublin, Lincoln Place, Dublin 2, Ireland

Email: Hal.Duncan@dental.tcd.ie

Tel: +35316127356

This article is protected by copyright. All rights reserved 


\section{ABSTRACT}

The European Society of Endodontology (ESE) is in the process of developing S3-Level Clinical Practice Guidelines for the treatment of pulpal and apical disease for the benefit of clinicians and patients. In order to ensure a homogenous review process in the development of the clinical practice guidelines, it is essential that the core outcomes for all endodontic treatments are standardised and recommendations are made regarding minimum follow up time specific to each outcome measure. In the absence of a recognised core outcome set in Endodontics, the current project aimed to follow an established consensus process to define the most appropriate clinician and patient-reported outcomes. As part of the project, recommendations will also be agreed regarding an acceptable minimum follow-up period for studies by literature review and group discussion. The selected outcome measures and follow-up periods will be used in subsequent systematic analyses of the literature to investigate the effectiveness of endodontic treatment to alleviate pulpitis and apical periodontitis. In this paper; previous reviews, ESE Guidelines and Position Statements were searched in order to compile a list of potentially important outcome measures for the treatment of pulpitis (working group 1), the non-surgical treatment of apical periodontitis (working group 2), the surgical treatment of apical periodontitis (working group 3 ) and the regenerative treatment of apical periodontitis (working group 4). Initially, the two S3 guideline leads selected two independent senior academics with experience of evidence-based dentistry to lead each of the four working groups forming a 10-member steering group. The working group leads in turn selected 32 academics with experience of evidence-based dentistry to lead the individual systematic reviews contained within the respective working groups. These 42 individuals make up the Guideline Development Group (GDG). Prior to the selected systematic reviewers commencing writing and submitting the review protocol, the complete list of outcome variables identified in this document will be ranked by the 42 members of the GDG in their importance to the individual patient using a 9-point Likert scale. A summary of the survey scores will thereafter be shared with the members of the group and the final list of clinician and patient-reported outcome measures rated as critical for decision making (7-9 on Likert scale by majority of survey participants) to guide systematic reviews will be consented and confirmed during an online meeting of the steering group. In this online meeting another aspect with regard to meaningfulness of clinical trial results to be addressed in systematic reviews will be consented: length of follow-up. In order to develop high quality guidelines, it is suggested that the follow-up period after treatment should be related to the specific outcome measure being addressed; however, a minimum of one year for assessing the effectiveness of treatments for pulpitis and apical periodontitis should be considered. It is accepted, that selected research questions that focus on pain, swelling, medication taken or investigating diagnostic accuracy are likely to have shorter follow-up periods. As a

This article is protected by copyright. All rights reserved 
result of the GDG consensus process the outcome measures and length of follow-up will, alongside the use of standard instruments to assess the methodological quality of clinical trials and other comparative studies, be applied to all the commissioned systematic reviews that will inform the subsequent process when developing the ESE S3 Level Clinical Practice Guidelines.

This article is protected by copyright. All rights reserved 


\section{DESCRIPTION OF OUTCOME-RELATED TERMS USED IN ESE S3 LEVEL GUIDELINES}

Outcome measures: Objective or subjective measurement used to evaluate the effectiveness of an intervention compared with the control (Smith et al. 2015). Outcome measures should be measurable, often using a numerical value (Nagendrababu et al. 2020). Endodontic outcome measures are specifically the measurements or analyses of pulpal and apical disease that are observed in a study or clinical trial that reflect the effectiveness of a therapy.

Clinical outcome: Measurable changes in disease, health, function or quality of life that evaluate the effectiveness of an intervention or exposure. Primary outcomes represent the most critical measures addressing the research question, whilst secondary outcomes assist in the interpretation and understanding of the primary outcome (Nagendrababu et al. 2021).

Clinician-reported outcomes: Assess the effectiveness of endodontic treatments using diagnostic tools and tests applied by clinicians, which measure the outcome of the disease (e.g. pulp sensibility test, periapical radiograph, cone-bean computed tomography).

Patient-reported outcomes: Assess the status of endodontically treated teeth from the patient's perspective without interpretation of the patient's response by a clinician or other individual (e.g. pain incidence, pain severity) (John 2018). Within Endodontics retaining a functional and asymptomatic tooth in the long term and a feeling of well-being are important patient-reported outcomes. Understanding the patient's perspective should facilitate the development of, patientcentred outcomes, which are the development of a set of outcome measures that are important to the patient during the treatment of pulpal and apical disease.

Clinical endpoint: The primary or secondary outcome measure that is being measured by a clinical trial. Often used interchangeably with outcome measure. The true clinical measure of a treatment outcome assesses the prevention and resolution of disease.

Surrogate endpoint: A measure of the effect of a specific treatment that may correlate with a real clinical endpoint, but does not have a guaranteed relationship (e.g. reduced biomarker expression in blood samples or alterations in bacterial levels in canals after root canal instrumentation). These endpoints are often used when the observation of clinical outcomes requires a long-term follow-up period (Bergenholtz \& Kvist 2014).

This article is protected by copyright. All rights reserved 
Validated surrogate endpoint: Surrogate measures that have been shown convincingly to relate the outcome of a patient's disease. For example, the radiographic reduction (but not resolution) of an apical radiolucency relates to other outcomes, such as decreased pain, increased tooth retention and resolution of disease.

Real clinical endpoint: A direct endpoint that is a true measure of disease prevention or resolution. For example, within Endodontics this may relate to the complete resolution of an apical radiolucency and reestablishment of a "normal" periodontal ligament space, tooth retention or absence of symptoms. A primary/secondary outcome measure should be important to the patient.

Efficacy and Effectiveness: Efficacy is the performance of an endodontic intervention under ideal and controlled conditions, whereas effectiveness refers to performance in 'real-world' pragmatic conditions. Effectiveness will be used rather than efficacy during the development of the ESE S3 level clinical practice guidelines.

\section{INTRODUCTION}

A recent focus on the development of patient-reported or centred-outcomes (Neelakantan et al. 2020), allied with new diagnostic modalities such as cone-beam computed tomography (CBCT) have highlighted the need to consider appropriate outcome measures to assess the effectiveness of endodontic treatment (Patel et al. 2021). Relevant outcomes are particularly pertinent when writing recommendations or undertaking systematic analysis of the literature in order to assist clinical guideline development using the Grading of Recommendations, Assessment, Development and Evaluations (GRADE) framework (Guyatt et al. 2008, Guyatt et al. 2011, Sanz et al. 2020).

Clinical guidelines contribute to an improvement in the quality of dental care for the general population by providing evidenced-based recommendations relevant to patients and clinicians, which later assist decision-making for treatment of specific diseases. The methodological characteristics of guideline development are defined in stages, with the first stage (S1) being guidelines that are based on 'recommendations by a selected group of experts'; the second stage (S2e and S2k) defining higher quality guidelines, which use formalised methodological techniques, and the third stage representing the highest 
quality and level of guidelines (S3) (Nothacker et al. 2014). S3 level guidelines are developed by a comprehensive formalized, systematic guideline development process.

Traditionally, the outcome of root canal treatment has been judged by clinician-reported measures using planar radiography, with less attention paid to patient-reported outcomes such as function, pain, tooth survival or quality of life (ESE 2006, Ng et al. 2007). As a result, there is a limited volume of evidence relating endodontic treatment outcomes to these patient-related factors in the literature (Bergenholtz \& Kvist 2014). Additionally, there are a range of outcomes after endodontic treatment, with the response of the disease to therapy being most commonly measured by a combination of clinician (radiographic, clinical healing) and patient-reported measures (symptoms, function and adverse effects). Other relevant outcomes may examine the longevity of tooth retention after therapy analysing whether endodontic treatment increases the probability of tooth survival, an important outcome measure for patients, which will take many more years to adequately assess (Tickle et al. 2008, $\mathrm{Ng}$ et al. 2011). Other less explored outcomes after endodontic therapy relate to the feeling of patient wellbeing or Oral Health Related Quality of Life (OHRQoL) (Neelkantan et al. 2020). Finally, the impact of persistent or emerging disease, retreatment or further treatment on the cost-effectiveness of treatment should also be considered an outcome measure relevant to both clinicians and patients respectively (Schwendicke \& Göstemeyer 2016).

Recently several disciplines have developed core outcome sets (COS), which represent a standardised list of outcomes that are measured and reported in clinical studies within a specific discipline (Williamson et al. 2012). Currently, a COS is not available within Endodontics. The lack of such standardised outcomes is reflected in the conclusions and quality of several systematic reviews reporting outcomes after root canal treatment (Ng et al. 2007) and vital pulp treatment (VPT) (Cushley et al. 2020) and is acknowledged in the recent ESE position statement addressing the management of deep caries and the exposed pulp (ESE 2019).

In the absence of a COS for Endodontics, the aim of this project was to select relevant and appropriate outcome measures using a consensus process that are evidenced-based and can help to standardise the outputs of the commissioned systematic reviews within the ESE S3 level guidelines for pulpal and apical disease. Recommendations and agreement will also be reached regarding the minimum follow up period for comparative studies to be included in the S3 level guideline process specific to each outcome measure selected in the consensus process.

\section{METHODOLOGY}

This article is protected by copyright. All rights reserved 
A complete list of outcome measures related to pulpitis and apical periodontitis will be generated in this document. Thereafter, the selection of a subgroup of appropriate outcome measures will be carried out by anonymised online voting by the members of the ESE S3 level guidelines steering committee (10 individuals) and by all of the invited systematic reviewers (32 individuals) involved in the guideline project. The 42 members represent the guideline development group (GDG). A complete list of outcome measures for the treatment of pulpitis and apical periodontitis are summarised in Table 1, which will be used for online assessment and prioritisation by all 42 members of the GDG.

\section{ESE S3 Level Guideline Development Group}

The ESE S3 level guideline process will consist of 42 global experts, who have previously agreed to take part in the guideline development process. All members will fulfil the following criteria for eligibility: i) working within the discipline of Endodontics or a related dental science; ii) have previously published in the area of evidenced-based dentistry; iii) have a minimum of 5 years academic experience postqualification iv) have no conflict of interest in developing ESE S3 level clinical guidelines. The group will be invited to participate in the identification and prioritisation of outcome measures outlined in this document.

\section{Initial steps}

A literature search of secondary evidence (and selected primary evidence) as well as relevant ESE position statements and guideline documents (ESE 2006, ESE 2016, ESE 2019) identified a range of clinician and patient-reported outcome measures for the treatment of pulpitis and apical periodontitis (see section 'Clinical outcome measures to be ranked for importance'). The range of surrogate and real outcome measures used within these documents are summarised and separated into clinician and patient-reported outcomes for four working groups, related to the treatment of pulpitis as well as the non-surgical, surgical and regenerative treatment of apical periodontitis (Table 2). Also at this stage, the list of outcome measures was shared with the eight-working group leads and comments were received about the completeness of the list with additional outcome measures added if necessary. In the next stage, the group of outcome measures will be ranked in importance by all members of the GDG using an online link sent directly to the GDG.

\section{Online Survey Process}

An online survey will be conducted among the ESE S3 GDG to reach consensus on which measures should be included. The GDG members, independently and confidentially, will be asked to evaluate the items in 
the survey based on the suitability and importance of each outcome measure for inclusion in all four working groups (WG).

The online survey will be carried out using the 9-point Likert scale recommended for assessing the importance of outcomes for GRADE (Guyatt et al. 2011): 1-3 Limited importance; 4-6 important; 7-9 critical importance. This will be related primarily to the relevance of the outcome measure to the patient. For example- a clinician-reported outcome measure (such as radiographic healing of an apical radiolucency) may be rated as, 6 or 7 -importance, as it has been shown scientifically to reflect patientreported outcome measures such as symptoms, pain and tooth function and survival.

The anonymous responses will be analysed and items with a score of 7-9 by more than $70 \%$ and items with a score of $1-3$ by less than $30 \%$ of members will be included as outcome measures in the guidelines. Alternatively, items with a score of $1-3$ by more than $70 \%$ and items with a score of 7-9 by less than $30 \%$ will be excluded. In round one all members will be asked to add further outcome measures if they deem them important. If necessary, the process will be continued with further rounds until a final set of clear and suitable items are developed for the guidelines. A final list of outcome measures rated as critical for decision making (7-9 on Likert scale) by majority of survey participants will be included. At the end of the consensus process, members will receive a summary of the results and any revised items.

\section{Clinical outcome measures to be ranked for importance}

In clinical medicine there are broadly two types of clinical endpoints, patient or clinician-reported (see 'descriptions of outcome related terms') with the US Food Drug Administration (FDA) (https://www.fda.gov/home) and the European Medicines Agency (EMA) (https://www.ema.europa.eu/en) both strongly requesting that data from patient-reported outcomes be considered in the assessment of clinical trial endpoints. Patient-reported outcomes classically include pain, swelling, function, survival, but may also include OHRQoL and cost-effectiveness analyses and should measure how the treated tooth feels, functions, or survives from the patient's perspective. These outcomes can be objective, such as tooth survival, disease exacerbation, or an adverse clinical event, or subjective including symptom score (e.g. visual analogue scale) or validated OHRQoL. The development of clinical guidelines using GRADE also insists that the outcomes at least consider the patient and are patient-centred; however, clinician-reported endpoints are the focus of the bulk of existing studies (Ng et al. 2007, 2011) and previous ESE guidelines (ESE 2006). Examples of clinician-reported outcomes are prevention of apical lesion development or resolution of an apical area on radiograph or alternatively response to pulp sensibility testing.

This article is protected by copyright. All rights reserved 
Endodontic research has also classically used surrogate measures to analyse outcome, such as negative bacterial culture (Sathorn et al. 2007), bacterial reduction assessed by molecular methods (Rôças \& Siqueira 2011) or biomarker expression (Maia et al. 2020), however, such markers may or may not convincingly relate to resolution or exacerbation of the patient's disease. Validated surrogate endpoints, which have been shown convincingly to relate the patients' disease, such as reduction of an apical radiolucency on radiograph, are considered more relevant (Schuster et al. 2019). These were traditionally categorised as being a 'loose' criteria for healing ( $\mathrm{Ng}$ et al. 2007), with 'strict' criteria (real clinical endpoints) requiring complete resolution of the apical radiolucency on planar film. Outcome has traditionally been assessed using 2-D planar radiography; however, with the advent of new imaging modalities such as CBCT possessing increased sensitivity (Kruse et al. 2019) compared with conventional radiography the likelihood of attaining complete healing has reduced particularly at early time-points (Patel et al. 2012). This may highlight that a surrogate measure of reduction of apical radiolucency (loose criteria) may be more relevant moving forward (Patel et al. 2020). It is important that outcome measures relate to resolution of disease rather than the technology (e.g. CBCT or planar film) as the bulk of available comparative studies investigating effectiveness will report using older techniques.

\section{WG 1: Outcome measures for treatment for pulpitis and prevention of apical periodontitis (Table 1)}

The assessment of VPT (and by extension pulpectomy) was described by the ESE $(2006,2019)$ as; "teeth should be carefully monitored by history and clinical examination at 6 months, supplemented by periapical radiograph at 1 year. If symptoms persist or there is uncertainty regarding healing, the tooth should continue to be assessed at regular intervals. Cold and electric pulp sensibility testing should be carried out to monitor pulpal response, noting that teeth with full pulpotomy or after pulpectomy will be unresponsive". The classic outcome measures relevant for VPT and pulpectomy are generally the prevention of apical periodontitis (as viewed by lack of emerging radiolucency on periapical radiograph) after at least one year. Therefore, for the S3 level guideline process a minimum follow-up of one year is likely to be acceptable to assess these features. Assessment of outcome measures related to the absence of pain, medication, swelling and other patient-related measures may be completed at shorter follow-up periods of one to two weeks; however, these should if possible be supplemented by analysis at longerterm time points. When considering the overall effectiveness other patient-related factors (e.g. OHRQoL) and cost-effectiveness may be considered again ideally at short and long-term time points. Firm 
recommendations of the appropriate length of follow-up will be made by steering group discussion after the appropriate outcome measures are selected.

\section{WG2: Outcome measures for non-surgical treatment of apical periodontitis (Table 1)}

The outcome measures for non-surgical root canal treatment and retreatment were described by the ESE (2006) as "The following findings indicate a favourable outcome: absence of pain, swelling and other symptoms, no sinus tract, no loss of function and radiological evidence of a normal periodontal ligament space around the root". It was suggested that root canal treatment should be assessed at least after one year and subsequently as required (ESE 2006). Reduction of an apical radiolucency on radiograph was described by the ESE as uncertain healing, but has also been referred to as healing by loose criteria (Ng et al. 2007, Ng et al. 2008). For the purposes of systematic review, it is proposed that a minimum follow up of one year is acceptable (Ørstavik 1996), with specific exceptions made for outcomes relating to studies addressing pain, swelling and other patient-related measures, as well as diagnostic accuracy studies.

\section{WG3: Outcome measures for the surgical treatment of apical periodontitis (Table 1)}

The outcome measures for healing following surgical endodontics (ESE 2006) were defined as "absence of pain, swelling and other symptoms, satisfactory healing of soft tissue, no sinus tract, no loss of function and radiological evidence of repair of apical periodontitis including reformation of the periodontal ligament space." This represents a combination of patient and clinician-reported endpoints, however, both are required as solely using a clinician-reported description of success as the percentage of apical radiolucency resolving in time, hold little or no significance to patients (e.g. $80 \%$ successful does not necessarily mean that the other $20 \%$ will give pain or the tooth will be lost).

As with non-surgical root canal treatment, surgical endodontics should be assessed after one year and subsequently as required. Therefore, similarly to WG1 and 2, a minimum follow-up of one year seems reasonable for systematic analysis of the literature with selected exceptions.

\section{WG4: Outcome measures for the regenerative treatment of apical periodontitis (Table 1)}

The effectiveness of tissue regeneration in treatment of apical periodontitis will be assessed by outcome measures similar to the outcome measures used after apical surgery (see WG3). The outcome of revitalization procedures, however, will be different to tissue regeneration during surgery and have been described in the ESE position statement (ESE 2016) as a favourable outcome being "No pain, no signs and symptoms of inflammation, healing of pre-existing bony periapical lesion, increase of root thickness and length, absence of (continued) external root resorption, positive response to sensibility testing, patient 
acceptance, no unacceptable colour changes; radiographic detection of a new PDL along the inner wall of the root canal." It appears reasonable that the follow up of revitalization procedures should be at a minimum of one year postoperatively, with longer follow up times preferable. Selected outcome measures such as discolouration and pain may be followed up at shorter time points; however, specific recommendations regarding appropriate minimum follow up for each outcome measure will be made at the end of the process.

\section{Online - meeting to finalise the outcome measures and follow-up period}

Following the online survey process, the list of outcome measures for the treatment of pulpitis, nonsurgical, surgical and regenerative treatment of apical periodontitis will be presented for further discussion and agreement with the 10 members of the steering group. The ESE S3 level project leader $(H D)$, will share the final results of the online consensus process, agenda of the meeting and the Zoom meeting link to the steering group seven days before the meeting. A final decision on follow up will also be made at this meeting. The project leader will chair the session. It is expected that a composite of patient and clinician-reported outcome measures will be finalised into the most important patientcentred outcomes during the meeting. Also, the minimum length of follow-up will be confirmed for the subsequent systematic reviews after the completion of the consensus process.

\section{Future plans}

The project lead (HD) will share the final list of outcome measures and follow-up period(s) with the GDG, which can then be used to develop the ESE S3 level clinical practice guidelines by systematic analysis of the literature and formal guideline process. The GDG anticipates it will be in a position to release the ESE S3 level clinical practice guideline in 2022/23.

\section{CONCLUSIONS}

In the systematic assessment of the effectiveness of an intervention in treating pulpitis or apical periodontitis an appropriate combination of patient and clinician-reported outcome measures should be applied. The proposed consensus process outlined in this document will identify a set of patient-centred core outcome measures for subsequent systematic review. An appropriate follow-up should also be identified for each outcome measure, generally being as long as possible with a minimum of one year appropriate for assessment the effectiveness of treatments for pulpitis and apical periodontitis. There will be selected exceptions to this in terms of studies examining the relief of symptoms, swelling or investigating diagnostic accuracy, which may be concluded after shorter time-frames. A second document 
demonstrating the results of the online consensus exercise after the appropriate outcome measures are finalised will be published.

\section{ACKNOWLEDGEMENT}

The authors acknowledge Professor Ina Kopp and Professor Moritz Kebschull who offered methodological advice and reviewed this manuscript.

\section{Conflict of Interest statement}

The authors have stated explicitly that there are no conflicts of interest in connection with this article.

This article is protected by copyright. All rights reserved 


\section{REFERENCES}

Bergenholtz G, Kvist T (2014) Evidence-based endodontics. Endodontic Topics 31, 3-18.

Cushley S, Duncan HF, Lappin MJ, Chua P, Elamin AD, Clarke M, El-Karim IA (2020) Efficacy of direct pulp capping for management of cariously exposed pulps in permanent teeth: a systematic review and metaanalysis. International Endodontic Journal doi: 10.1111/iej.13449. Epub ahead of print.

ESE (2006) Quality guidelines for endodontic treatment: consensus report of the European Society of Endodontology. International Endodontic Journal 39, 921-30.

ESE (2016) European Society of Endodontology position statement: Revitalization procedures. International Endodontic Journal 49, 717-23.

ESE (2019) European Society of Endodontology position statement: Management of deep caries and the exposed pulp. International Endodontic Journal 52, 923-34.

Guyatt GH, Oxman AD, Vist GE et al. (2008) GRADE: an emerging consensus on rating quality of evidence and strength of recommendations. BMJ 336, 924-6.

Guyatt GH, Oxman AD, Kunz R, et al. (2011) GRADE guidelines: 2. Framing the question and deciding on important outcomes. Journal of Clinical Epidemiology 64, 395-400.

John MT (2018) Health outcomes reported by dental patients. Journal of Evidence Based Dental Practice $18,332-5$.

Kruse C, Spin-Neto R, Evar Kraft DC, Vaeth M, Kirkevang LL (2019) Diagnostic accuracy of cone beam computed tomography used for assessment of apical periodontitis: an ex vivo histopathological study on human cadavers. International Endodontic Journal 52, 439-50.

Loos BG, Needleman I (2020) Endpoints of active periodontal therapy. Journal of Clinical Periodontology 47 (Suppl 22), 61-71.

Maia LM, Espaladori MC, Diniz JMB, Tavares WLF, de Brito LCN, Vieira LQ, Sobrinho APR (2020) Clinical endodontic procedures modulate periapical cytokine and chemokine gene expressions. Clinical Oral Investigations 24, 3691-7.

Nagendrababu V, Duncan HF, Pulikkotil SJ, Dummer PMH (2021) Glossary for randomized clinical trials. International Endodontic Journal 54, 354- 65

Nagendrababu V, Dilokthornsakul P, Jinatongthai P, Veettil SK, Pulikkotil SJ, Duncan HF, Dummer PMH (2020) Glossary for systematic reviews and meta-analyses. International Endodontic Journal 53, 232-49.

Neelakantan P, Liu P, Dummer PMH, McGrath C (2020) Oral health-related quality of life (OHRQoL) before and after endodontic treatment: a systematic review. Clinical Oral Investigations 24, 25-36.

This article is protected by copyright. All rights reserved 
Ng YL, Mann V, Rahbaran S, Lewsey J, Gulabivala K (2007) Outcome of primary root canal treatment: systematic review of the literature - part 1 . Effects of study characteristics on probability of success. International Endodontic Journal 40, 921-39.

Ng YL, Mann V, Gulabivala K (2008) Outcome of secondary root canal treatment: a systematic review of the literature. International Endodontic Journal 41, 1026-46.

Ng YL, Mann V, Gulabivala K (2010) Tooth survival following non-surgical root canal treatment: a systematic review of the literature. International Endodontic Journal 43, 171-89.

Nothacker MJ, Muche-Borowski C, Kopp IB (2014) Guidelines in the Register of the Association of Scientific Medical Societies in Germany - A Quality Improvement Campaign. Geburtshilfe und Frauenheilkunde 74, 260-6.

$\emptyset$ rstavik D (1996) Time-course and risk analyses of the development and healing of chronic apical periodontitis in man. International Endodontic Journal 29, 150-5.

Patel S, Wilson R, Dawood A, Foschi F, Mannocci F (2012) The detection of periapical pathosis using digital periapical radiography and cone beam computed tomography - Part 2: a 1-year post-treatment follow-up. International Endodontic Journal 45, 711-23.

Patel S, Arias A, Whitworth J, Mannocci F (2020) Outcome of endodontic treatment - the elephant in the room. International Endodontic Journal 53, 291-7.

Rôças IN, Siqueira JF Jr (2011) Comparison of the in vivo antimicrobial effectiveness of sodium hypochlorite and chlorhexidine used as root canal irrigants: a molecular microbiology study. Journal of Endodontics 37, 143-50.

Sanz M, Herrera D, Kebschull M, Chapple I, Jepsen S, Beglundh T, Sculean A, Tonetti MS; EFP Workshop Participants and Methodological Consultants (2020) Treatment of stage I-III periodontitis-The EFP S3 level clinical practice guideline. Journal of Clinical Periodontology 47 (Suppl 22), 4-60.

Sathorn C, Parashos P, Messer HH (2007) How useful is root canal culturing in predicting treatment outcome? Journal of Endodontics 33, 220-5.

Schuster Bruce C, Brhlikova P, Heath J, McGettigan P (2019) The use of validated and nonvalidated surrogate endpoints in two European Medicines Agency expedited approval pathways: A cross-sectional study of products authorised 2011-2018. PLoS Medicine 16, e1002873.

Schwendicke F, Göstemeyer G (2016) Cost-effectiveness of Single- Versus Multistep Root Canal Treatment. Journal of Endodontics 42, 1446-52.

Smith PG, Morrow RH, Ross DA, eds. (2015) Outcome measures and case definition. In: Field Trials of Health Interventions: A Toolbox, 3rd edn. Oxford: OUP.

This article is protected by copyright. All rights reserved 
Tickle M, Milsom K, Qualtrough A, Blinkhorn F, Aggarwal VR (2008) Summary of: The failure rate of NHS funded molar endodontic treatment delivered in general dental practice. British Dental Journal 204, 2545.

Williamson PR, Altman DG, Blazeby JM, Clarke M, Devane D, Gargon E, Tugwell P (2012) Developing core outcome sets for clinical trials: issues to consider. Trials 13, 132.

This article is protected by copyright. All rights reserved 
Table 1: Proposed outcome measures for use in the development of European Society of Endodontology S3 level clinical practice guidelines.

\begin{tabular}{|c|c|c|c|c|c|c|c|}
\hline \multicolumn{2}{|c|}{ Treatment of Pulpitis } & \multicolumn{2}{|c|}{$\begin{array}{c}\text { Non-Surgical Treatment of Apical } \\
\text { Periodontitis }\end{array}$} & \multicolumn{2}{|c|}{$\begin{array}{c}\text { Surgical Treatment of Apical } \\
\text { Periodontitis }\end{array}$} & \multicolumn{2}{|c|}{$\begin{array}{c}\text { Regenerative Treatment of Apical } \\
\text { Periodontitis }\end{array}$} \\
\hline CROM & PROM & CROM & PROM & CROM & PROM & CROM & PROM \\
\hline $\begin{array}{l}\text { Tenderness to } \\
\text { percussion }\end{array}$ & Pain & $\begin{array}{l}\text { Tenderness to } \\
\text { percussion }\end{array}$ & Pain & $\begin{array}{l}\text { Tenderness to } \\
\text { percussion }\end{array}$ & Pain & $\begin{array}{l}\text { Tenderness to } \\
\text { percussion }\end{array}$ & Pain \\
\hline $\begin{array}{l}\text { Tenderness to } \\
\text { Palpation }\end{array}$ & Tenderness & $\begin{array}{c}\text { Tenderness to } \\
\text { Palpation }\end{array}$ & Tenderness & $\begin{array}{c}\text { Tenderness to } \\
\text { Palpation }\end{array}$ & Tenderness & $\begin{array}{c}\text { Tenderness to } \\
\text { Palpation }\end{array}$ & Tissue Tenderness \\
\hline Sinus tract & Swelling & Sinus tract & Swelling & Sinus tract & Swelling & Sinus tract & Swelling \\
\hline $\begin{array}{l}\text { Response to pulp } \\
\text { sensibility test (not } \\
\text { full pulpotomy or } \\
\text { pulpectomy) }\end{array}$ & Foul taste & Mobility & $\begin{array}{c}\text { Tooth function } \\
\text { (Fracture, } \\
\text { restoration } \\
\text { longevity) }\end{array}$ & Mobility & $\begin{array}{c}\text { Tooth function } \\
\text { (Fracture, } \\
\text { restoration } \\
\text { longevity) }\end{array}$ & Mobility & $\begin{array}{c}\text { Tooth function } \\
\text { (Fracture, } \\
\text { restoration } \\
\text { longevity) }\end{array}$ \\
\hline $\begin{array}{c}\text { Radiographic } \\
\text { evidence of } \\
\text { resorption }\end{array}$ & Tooth function & Periodontal pocket & Mobility & Periodontal pocket & Mobility & Swelling & Mobility \\
\hline $\begin{array}{l}\text { Radiographic } \\
\text { evidence of hard } \\
\text { tissue dentine bridge }\end{array}$ & QHRQoL & Bacterial reduction & QHRQoL & $\begin{array}{c}\text { Radiographic } \\
\text { evidence of apical } \\
\text { lesion size (loose }\end{array}$ & QHRQoL & $\begin{array}{l}\text { Response to pulp } \\
\text { sensibility test (not } \\
\text { full pulpotomy or }\end{array}$ & QHRQoL \\
\hline
\end{tabular}

This article is protected by copyright. All rights reserved 


\begin{tabular}{|c|c|c|c|c|c|c|c|}
\hline $\begin{array}{l}\text { formation following } \\
\text { pulp } \\
\text { capping/pulpotomy }\end{array}$ & & & & criteria) & & pulpectomy) & \\
\hline $\begin{array}{c}\text { Radiographic } \\
\text { evidence of continued } \\
\text { root formation }\end{array}$ & $\begin{array}{c}\text { Adverse effects } \\
\text { (exacerbation, } \\
\text { restoration integrity) }\end{array}$ & $\begin{array}{c}\text { Intracanal or } \\
\text { periapical biomarker } \\
\text { expression }\end{array}$ & $\begin{array}{l}\text { Adverse effects } \\
\text { (exacerbation, } \\
\text { restoration } \\
\text { integrity) }\end{array}$ & $\begin{array}{c}\text { Radiographic } \\
\text { evidence of apical } \\
\text { radiolucency and } \\
\text { normal periodontal } \\
\text { ligament space } \\
\text { (strict criteria) }\end{array}$ & $\begin{array}{l}\text { Adverse effects } \\
\text { (exacerbation, } \\
\text { discharge) }\end{array}$ & $\begin{array}{c}\text { Radiographic } \\
\text { evidence of } \\
\text { external resorption }\end{array}$ & $\begin{array}{c}\text { Possible adverse } \\
\text { effects }\end{array}$ \\
\hline $\begin{array}{c}\text { Cost-effectiveness of } \\
\text { procedure }\end{array}$ & $\begin{array}{l}\text { Need for further } \\
\text { intervention }\end{array}$ & $\begin{array}{c}\text { Radiographic } \\
\text { evidence of apical } \\
\text { lesion size (loose } \\
\text { criteria) }\end{array}$ & $\begin{array}{l}\text { Need for further } \\
\text { intervention }\end{array}$ & $\begin{array}{c}\text { Cost-effectiveness of } \\
\text { procedure }\end{array}$ & $\begin{array}{l}\text { Post-surgical } \\
\text { gingival } \\
\text { aesthetics }\end{array}$ & $\begin{array}{c}\text { Radiographic } \\
\text { evidence of apical } \\
\text { lesion size }\end{array}$ & Discolouration \\
\hline 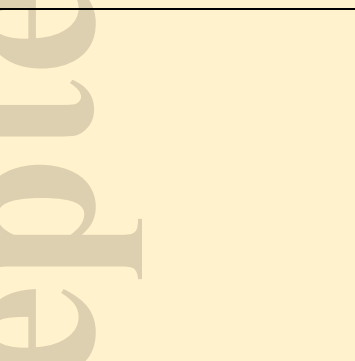 & $\begin{array}{l}\text { Need for medication } \\
\text { (analgesics) }\end{array}$ & $\begin{array}{c}\text { Radiographic } \\
\text { evidence of apical } \\
\text { radiolucency and } \\
\text { normal periodontal } \\
\text { ligament space (strict } \\
\text { criteria) }\end{array}$ & $\begin{array}{l}\text { Need for medication } \\
\text { (analgesics, } \\
\text { antibiotics) }\end{array}$ & & $\begin{array}{l}\text { Need for further } \\
\text { intervention }\end{array}$ & $\begin{array}{c}\text { Radiographic } \\
\text { evidence of apical } \\
\text { radiolucency and } \\
\text { normal periodontal } \\
\text { ligament space }\end{array}$ & $\begin{array}{l}\text { Need for further } \\
\text { intervention }\end{array}$ \\
\hline & Need for sick leave & $\begin{array}{l}\text { Radiographic signs of } \\
\text { continuing resorption }\end{array}$ & Need for sick leave & & $\begin{array}{l}\text { Need for } \\
\text { medication } \\
\text { (analgesics, } \\
\text { antibiotics) }\end{array}$ & $\begin{array}{l}\text { Radiographic } \\
\text { evidence of } \\
\text { periodontal } \\
\text { ligament on inner } \\
\text { root canal wall }\end{array}$ & $\begin{array}{l}\text { Need for medication } \\
\text { (analgesics, } \\
\text { antibiotics) }\end{array}$ \\
\hline
\end{tabular}

This article is protected by copyright. All rights reserved 


\begin{tabular}{|l|c|c|c|c|c|c|}
\hline & $\begin{array}{c}\text { Cost-effectiveness of } \\
\text { procedure }\end{array}$ & $\begin{array}{c}\text { Cost-effectiveness of } \\
\text { procedure }\end{array}$ & $\begin{array}{c}\text { Cost-effectiveness of } \\
\text { procedure }\end{array}$ & $\begin{array}{c}\text { Need for sick } \\
\text { leave }\end{array}$ & $\begin{array}{c}\text { Radiographic } \\
\text { evidence of root } \\
\text { thickness and } \\
\text { angth }\end{array}$ & $\begin{array}{c}\text { Need for sick leave } \\
\text { length }\end{array}$ \\
\hline & & & & $\begin{array}{c}\text { Cost-effectiveness } \\
\text { of procedure }\end{array}$ & $\begin{array}{c}\text { Cost-effectiveness } \\
\text { of procedure }\end{array}$ & $\begin{array}{c}\text { Cost-effectiveness of } \\
\text { procedure }\end{array}$ \\
\hline
\end{tabular}

CROM - Clinician-reported outcome measures, PCOM - Patient-reported outcome measures, QHRQoL - Oral Health-Related Quality of Life

This article is protected by copyright. All rights reserved 
Table 2: Working groups involved in developing European Society of Endodontology S3 level clinical practice guidelines

\begin{tabular}{|l|l|}
\hline Working Group & Themes \\
\hline 1 & The Treatment of Pulpitis \\
\hline 2 & The Non-Surgical Treatment of Apical Periodontitis \\
\hline 3 & The Surgical Treatment of Apical Periodontitis \\
\hline 4 & The Regenerative Treatment of Apical Periodontitis \\
\hline
\end{tabular}

This article is protected by copyright. All rights reserved 